\title{
Speciation of nitrogen bearing species using negative and positive secondary ion spectra with Nano Secondary lon Mass Spectrometry
}

\author{
Kexue Li, ${ }^{\S}$ Baerbel Sinha, ${ }^{\S}$,, Peter Hoppe, ${ }^{\S}$ \\ ${ }^{\S}$ Particle Chemistry Department, Max Planck Institute for Chemistry, Mainz, Germany \\ "Department of Earth and Environmental Sciences, Indian Institute of Science Education and Research Mohali, \\ Sector 81 SAS Nagar, Manauli P.O. 140306, India
}

\begin{abstract}
In this study we demonstrate that Nano Secondary Ion Mass Spectrometry (NanoSIMS) can be used to differentiate different nitrogen containing species commonly observed in atmospheric aerosol particles with micrometer or sub-micrometer spatial resolution, on the basis of the relative intensity of secondary ion signals, both in negative and positive secondary ion mode, without the need to chemically or physically separate the samples. Compounds tested include nitrate, nitrite, ammonium salts, urea, amino acids, sugars, organic acids, amides, triazine, imidazole, protein and biological tissue. We show that $\mathrm{NO}_{2}{ }^{-}$secondary ions are unique to the decomposition of nitrate and nitrite salts, while $\mathrm{NH}_{4}^{+}$secondary ions are unique to samples containing ammonium ions, with low signal intensities observed from amino groups, but none from biological tissue. $\mathrm{CN}^{-}$signals are obtained from all nitrogen bearing compounds but relative signal intensities are the highest for organic nitrogen containing compounds. We demonstrate, that quantitative determination of the elemental fractions of carbon, oxygen and nitrate in nanometre sized aerosol samples using normalized secondary ion intensities is possible. We further demonstrate that stable isotope ratios measured on in-house standards of unknown isotopic composition using the ${ }^{12} \mathrm{C}^{15} \mathrm{~N}^{-} /{ }^{12} \mathrm{C}^{14} \mathrm{~N}^{-}$- ratio (all nitrogen containing species), the ${ }^{15} \mathrm{~N}^{16} \mathrm{O}_{2}^{-} /{ }^{14} \mathrm{~N}^{16} \mathrm{O}_{2}^{-}$- ratio (nitrate and nitrite species) and the ${ }^{15} \mathrm{NH}_{4}{ }^{+} /{ }^{14} \mathrm{NH}_{4}{ }^{+}$- ratio (ammonium salts, amino acids and urea) are stable and sufficiently precise for nitrogen isotope analysis.
\end{abstract}

\section{Table of contents for supplementary material:}

Table S1. Inorganic and organic standards used in this study. $\quad$ Pages $\mathrm{S}_{2}-\mathrm{S}_{3}$

Table S2. Concentrations of solutions used to make aerosol-like mixture samples $\quad$ Page S3-S4

Figure $\mathrm{S}_{3}$ : Signal intensity of ${ }^{14} \mathrm{~N}^{16} \mathrm{O}_{2}{ }^{-}$and ${ }^{14} \mathrm{NH}_{4}{ }^{+}$molecular ions in different samples $\quad$ Page $\mathrm{S}_{4}$

Figure $\mathrm{S}_{4}$ : NanoSIMS images of the same area in negative (top) and positive (bottom) secondary ion modes. The corresponding SEM image is shown in the lower right. Primary biological particles - fungal hyphen aerosol was collected on silicon wafer. Field of view is $30 \times 30 \mu \mathrm{m}^{2}$.

Page $\mathrm{S}_{4}$

Figure $\mathrm{S}_{5}$ : Ambient aerosol samples from the Amazon rain forest. Green rectangular box: potassium sulfate $+\mathrm{SOA}+$ POA, yellow rectangular box: soot + salt coating and blue rectangular box: ammonium sulfate + SOA. Page $\mathrm{S}_{5}$ 
Table $S_{3}$. Inorganic and organic standards used in this study.

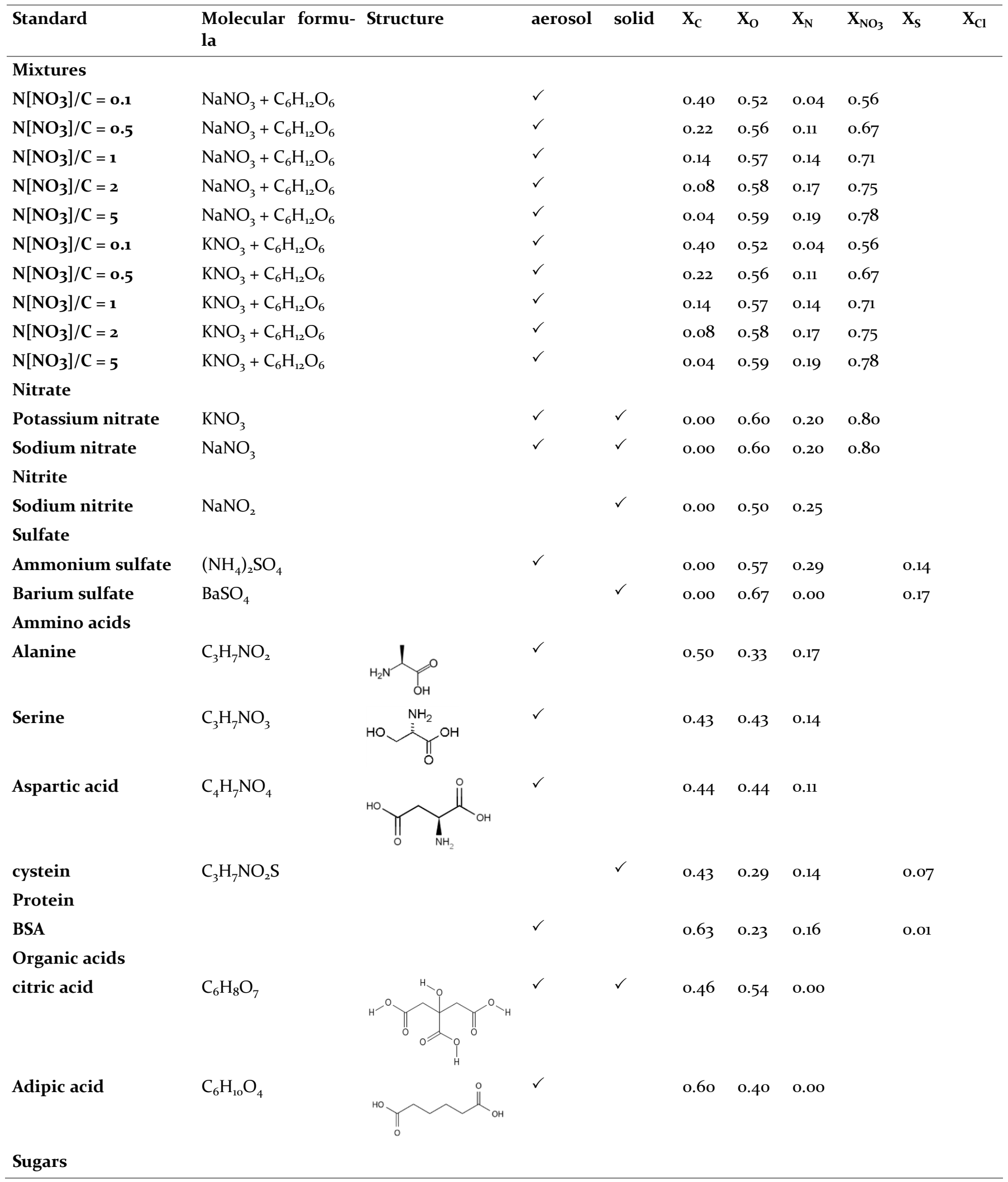




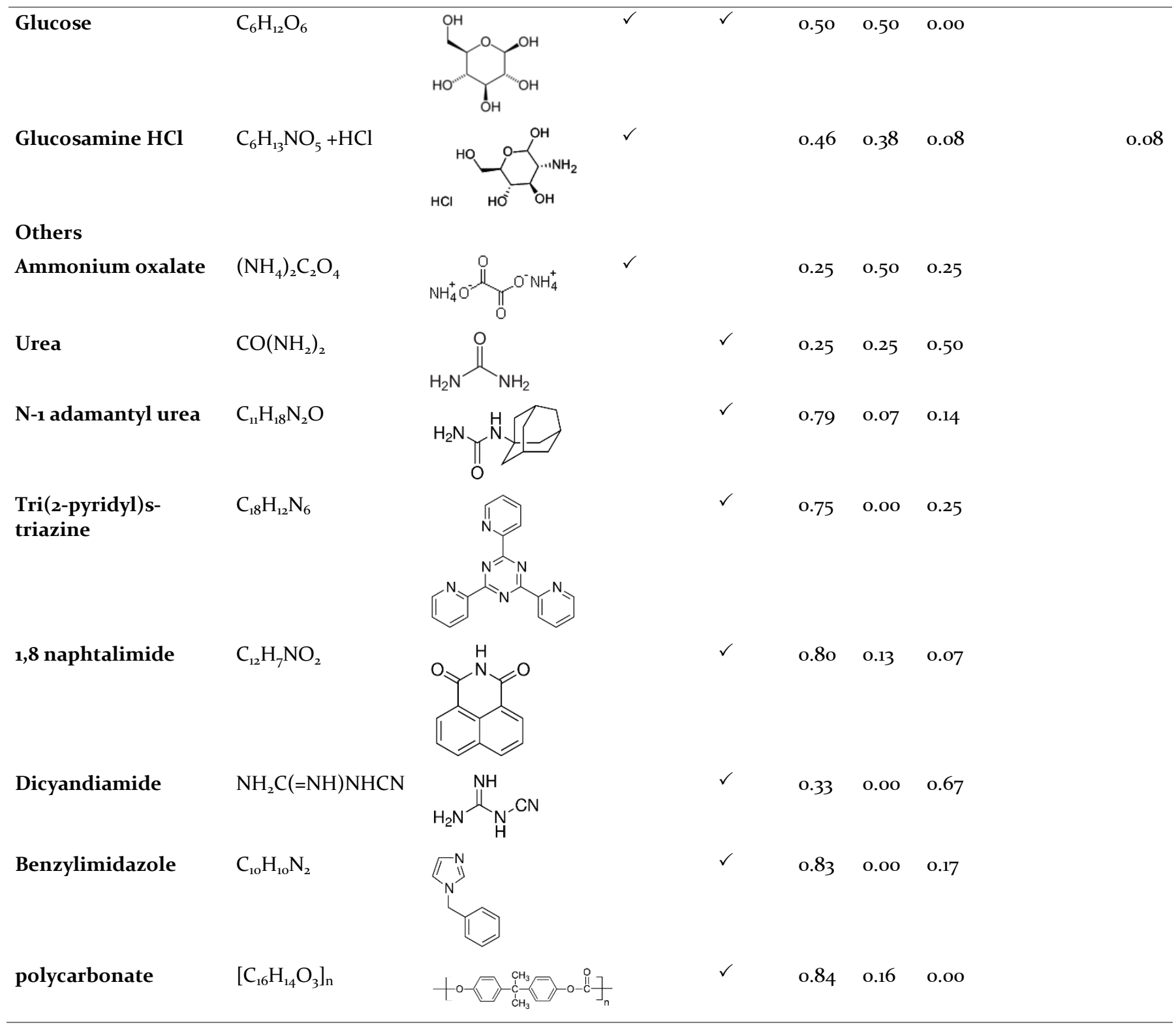

Table S4. Concentrations of solutions used to make aerosol-like mixture samples.

\begin{tabular}{|c|c|c|c|}
\hline Standard & Sodium nitrate $\left(\mathrm{NaNO}_{3}\right)$ & \multicolumn{2}{|c|}{ 2-Deoxy-D-glucose $\left(\mathrm{C}_{6} \mathrm{H}_{12} \mathrm{O}_{6}\right)$} \\
\hline Molar mass & 85.00 & 180.16 & \\
\hline $\mathrm{N}$ or $\mathrm{C}$ atom number & 1 & 6 & \\
\hline Samples & $\mathrm{N} / \mathrm{C}$ & $\mathrm{NaNO}_{3}(\mathrm{~g} / \mathrm{L})$ & $\begin{array}{l}\text { 2-Deoxy-D-glucose } \\
\left(\mathrm{C}_{6} \mathrm{H}_{12} \mathrm{O}_{6}\right)(\mathrm{g} / \mathrm{L})\end{array}$ \\
\hline $\mathrm{NaNO}_{3}-\mathrm{C}-1$ & 0.1 & 4.41 & 15.59 \\
\hline $\mathrm{NaNO}_{3}-\mathrm{C}-2$ & 0.5 & 11.72 & 8.28 \\
\hline $\mathrm{NaNO}_{3}-\mathrm{C}-3$ & 1 & 14.78 & 5.22 \\
\hline $\mathrm{NaNO}_{3}-\mathrm{C}-4$ & 2 & 17.00 & 3.00 \\
\hline
\end{tabular}




\begin{tabular}{llll}
\hline $\mathrm{NaNO}_{3}-\mathbf{C}-5$ & 5 & 18.68 & 1.32 \\
\hline Standards & Potassium nitrate $\left(\mathrm{KNO}_{3}\right)$ & 2-Deoxy-D-glucose $\left(\mathbf{C}_{\mathbf{6}} \mathbf{H}_{\mathbf{1 2}} \mathbf{O}_{\mathbf{6}}\right)$ \\
\hline Molar mass & 101.00 & 180.16 & \\
Samples & $\mathrm{N} / \mathrm{C}$ & $\mathrm{KNO}_{3}(\mathrm{~g} / \mathrm{L})$ & 2 -Deoxy-D-glucose \\
& & & $\left(\mathrm{C}_{6} \mathrm{H}_{12} \mathrm{O}_{6}\right)(\mathrm{g} / \mathrm{L})$ \\
$\mathrm{KNO}_{3}-\mathrm{C}-1$ & 0.1 & 5.03 & 14.97 \\
$\mathrm{KNO}_{3}-\mathrm{C}-2$ & 0.5 & 12.54 & 7.46 \\
$\mathrm{KNO}_{3}-\mathrm{C}-3$ & 1 & 15.42 & 4.58 \\
$\mathrm{KNO}_{3}-\mathrm{C}-4$ & 2 & 17.41 & 2.59 \\
$\mathrm{KNO}_{3}-\mathrm{C}-5$ & 5 & 18.88 & 1.12 \\
\hline
\end{tabular}
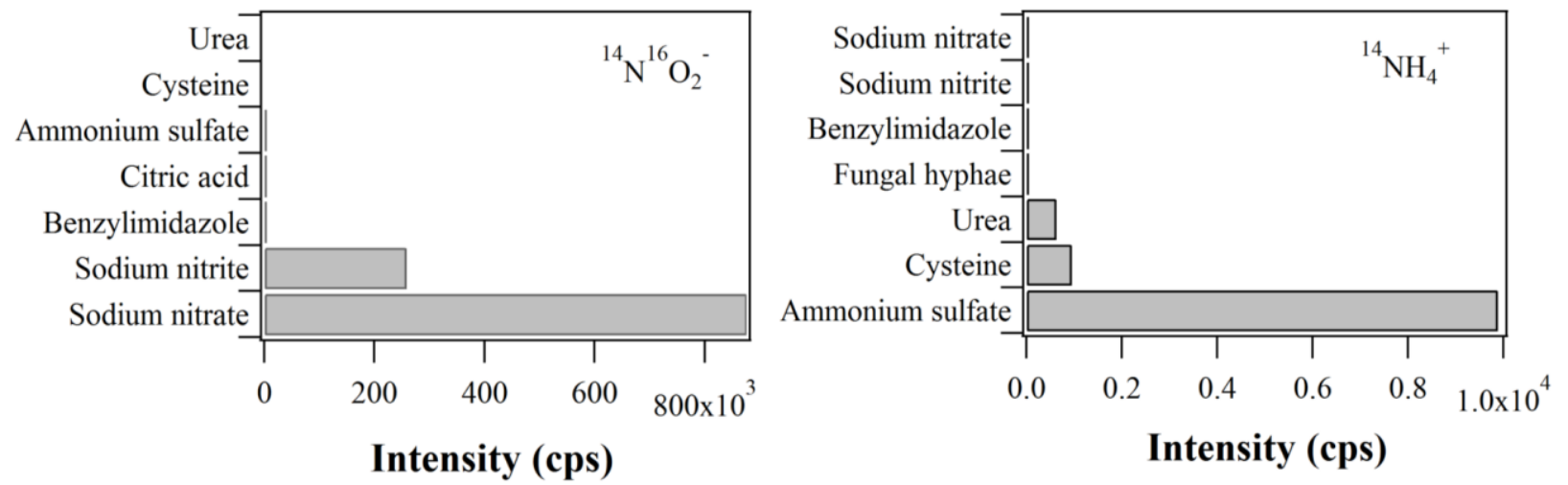

Figure $\mathrm{S}_{3}$ : Signal intensity of ${ }^{14} \mathrm{~N}^{16} \mathrm{O}_{2}{ }^{-}$and ${ }^{14} \mathrm{NH}_{4}{ }^{+}$molecular ions in different samples 

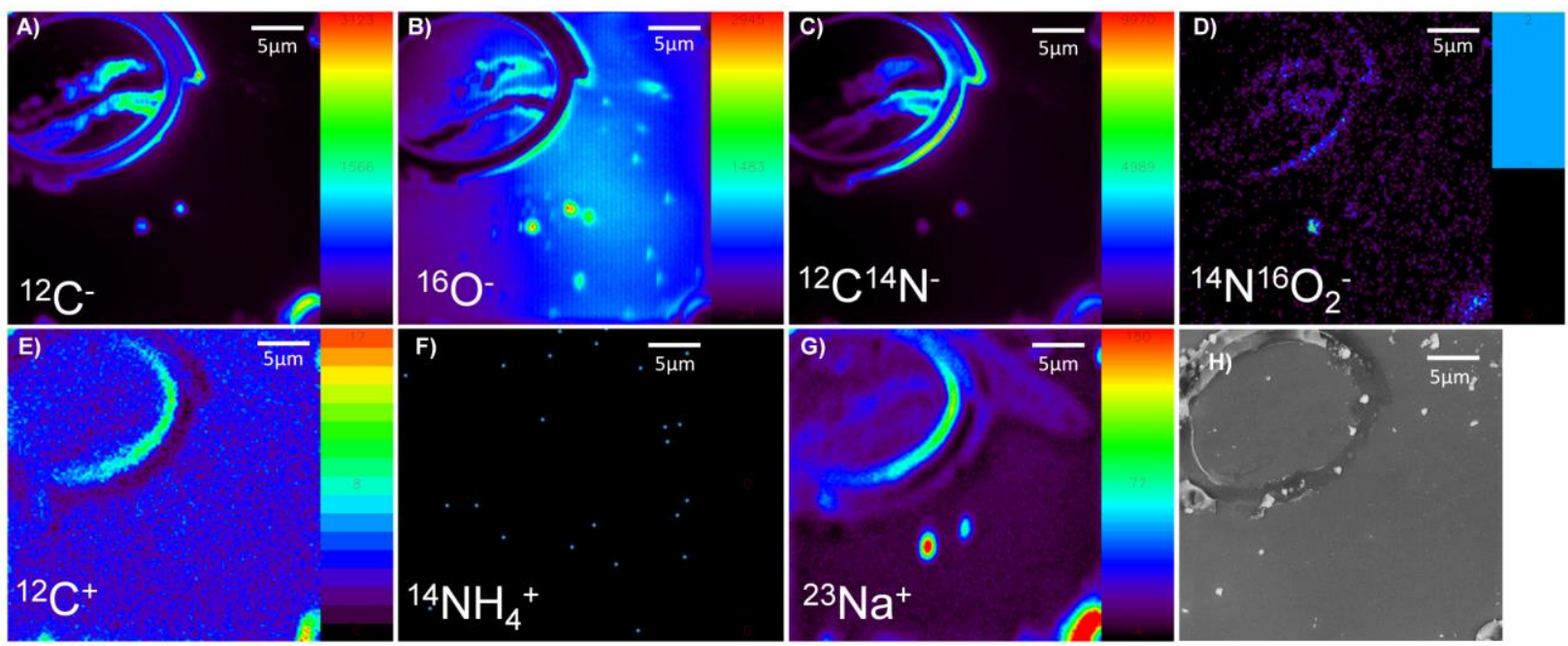

Figure S4: NanoSIMS images of the same area in negative (top) and positive (bottom) secondary ion modes. The corresponding SEM image is shown in the lower right. Primary biological particles - fungal hyphen aerosol was collected on silicon wafer. Field of view is $30 \times 30 \mu \mathrm{m}^{2}$.

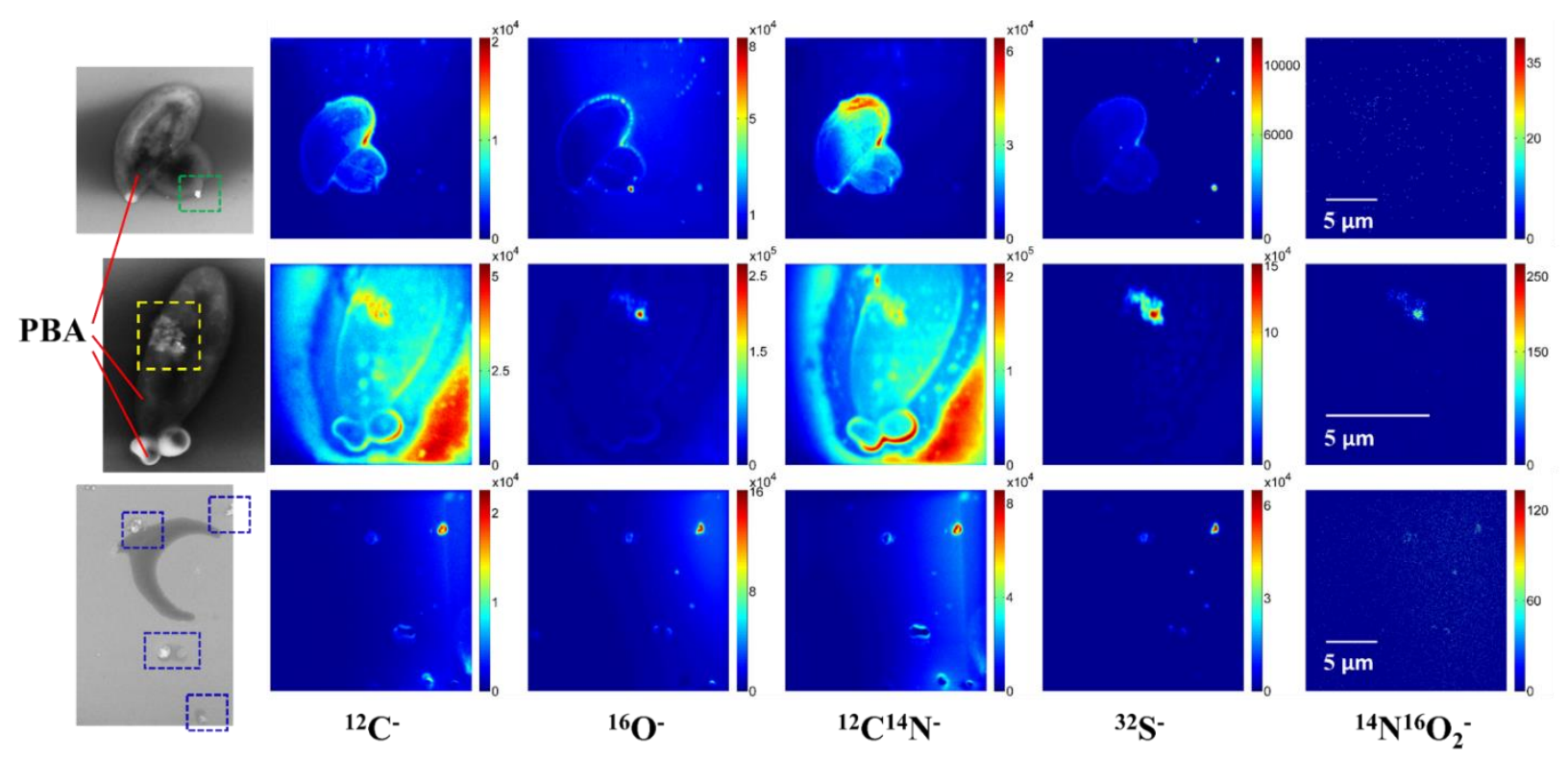

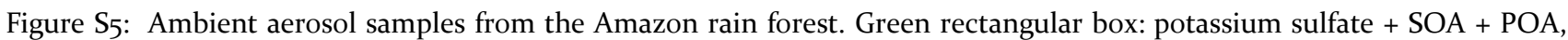
yellow rectangular box: soot + salt coating and blue rectangular box: ammonium sulfate + SOA. 